\title{
Transatlantica
}

Revue d'études américaines. American Studies Journal

Gone With the Wind after Gone With the Wind

\section{Seeing Margaret Mitchell's Gone With the Wind with Fresh Eyes}

\section{Emmeline Gros}

\section{(2) OpenEdition}

1 Journals

\section{Electronic version}

URL: https://journals.openedition.org/transatlantica/14172

DOI: $10.4000 /$ transatlantica. 14172

ISSN: 1765-2766

\section{Publisher}

Association française d'Etudes Américaines (AFEA)

\section{Electronic reference}

Emmeline Gros, "Seeing Margaret Mitchell's Gone With the Wind with Fresh Eyes", Transatlantica [Online], 1 | 2019, Online since 01 July 2020, connection on 31 January 2023. URL: http:// journals.openedition.org/transatlantica/14172 ; DOI: https://doi.org/10.4000/transatlantica.14172

This text was automatically generated on 31 January 2023

\section{(c) (i) (9)}

Creative Commons - Attribution-NonCommercial-NoDerivatives 4.0 International - CC BY-NC-ND 4.0 https://creativecommons.org/licenses/by-nc-nd/4.0/ 


\title{
Seeing Margaret Mitchell's Gone With the Wind with Fresh Eyes
}

\author{
Emmeline Gros
}

"the idea that women should be free from considerations [of beauty] is rather recent"

(Moore).

"Why, after decades of feminism, do we seem to demand that women in the public eye be extraordinarily beautiful but their male counterparts can get away with being ordinary?"

“Scarlett O'Hara was not beautiful, but men seldom realized it when caught by her charm as the Tarleton twins were" (Mitchell 3).

1 In "A New Image of Female Authenticity," columnist Anan Giridharadas explains that "what remains impregnable to [women] are those refuges that shelter so many men: ordinariness and muddling through." Only very recently, the article continues, have women started "clamoring for a freedom long cherished by men: the right to be ugly, too" (N.Y Times, 2013).

2 In the light of the article cited above, anyone interested in the question of the representations of gender in Mitchell's work should re-open and re-read the first page of Gone With the Wind. Obviously, Margaret Mitchell's deliberate choice to present Scarlett as someone who was "not beautiful" (3) reads as a deviation from the gender orthodoxy presented by the N.Y Times article. In doing so, one could say that Mitchell clearly wished to establish Gone With the Wind as a liberating narrative-one that sought to authorize deviating female representations in the plantation novel. She did so in two different ways: first, she refused to partake in the tyranny of what southern scholar W.J. Cash has termed "gyneolatry"-the "worship of the beautiful white woman upon which so much retrogressive southern ideology has been based" (86, qtd. in Miller 1); second, she refused complicity in the dehumanizing materiality carried by the adjective 
"beautiful," thereby bringing forth a very modern way of imagining white woman's right to be ugly.

3 Much of Mitchell's modernity, however, seems to have escaped critical attention. Of course, the choice of Vivien Leigh-recognized as "the greatest beauty of her time" by The Observer-may also explain why the opening five words of Mitchell's novel have misdirected more than one scholar on the subject. Critics of Gone With the Wind have been largely intent to reflect on the (incomprehensible) endurance of both novel and movie (Watkins); the "pro-Confederate propaganda" work it performs (Boot); the dangers of Gone With The Wind's romantic vision of the Old South (Feuerherd); the problematic "portrait of a never-never land whose harmony and grace depended on the smoothing out of much that was ugly and uncomfortable" (Haskell); the "sexualized power dynamics of Scarlett and Rhett couple" (Crank); the representations of a white Southern femininity gone bad (Entzminger and Miller), or "the question of the representation of race" (Jerng), to name some of the themes. In so doing, it seems that they have forgotten that when we celebrate the beauty of the plantation South and one of its most enduring couples, Scarlett O'Hara and Rhett Butler, we also celebrate Scarlett's ugliness, Rhett's rogueness and bestiality, and the couple's aversion to participating in a regulatory fiction of gender performance which upholds the social status quo (Butler 520).

Beauty (like ugliness) is in the eye of the beholder. Such goes the popular saying. This expression entails that one should "see" beyond facial and physical body features. Miller, in a recent publication on the subject, reminds us that "ugliness, like beauty, is an aesthetic judgment that results from an interaction between a viewer and one who is viewed" (62). To be ugly is first and foremost to be seen as ugly; to be judged as an ugly female character against standards and norms that constitute what Southerners would consider beautiful. Interesting also is the question of who sees, of whose gaze has the power to assess that Scarlett is ugly or that she does not conform to the societal expectations associated with traditional bellehood. The initial presentation of Scarlett speaks precisely to the power of her charms to supersede the power of the gaze, thereby demonstrating the fragility of the traditional male gaze on the female body.

The question of what makes Scarlett ugly/not beautiful, or what frees her (or not) from considerations of beauty, has been addressed repeatedly by critics over the past 80 years. Their reflection has often centered around how ugliness-often embedded in questions of race (Miller) or gyneolatry (Cash)-is deployed in Gone With the Wind and to what end. What these critics tell us is that when such women are called ugly, they are simply non-compliant (Moore). ${ }^{1}$ For this reason, Miller concludes that, in the novel, "Scarlett's striking lack of beauty functions as a marker of defiance against societal standards and expectations" (60). ${ }^{2}$

Posing Scarlett as a non-compliant Southern belle obfuscates, I believe, a well-deserved close attention to the gendered dynamics of vision-what Mary Anne Doane names "the sexual politics of looking" (86)-at the core of Mitchell's text. I argue that shifting the focus away from Scarlett's ugliness to how this judgement is made may also explain the sources and meaning of Gone With the Wind's continued popularity: the text, as I will show, requires its readers to follow the (visual) cues of an unreliable narrator, faulty onlookers, and untrustworthy actors. This, in turn, will help us address the other dimension of the readerly experience in Mitchell's novel, namely that readers might need to learn to disregard the evidence of their own eyes. 
7 The representation of Scarlett, the focus of this essay, has been constructed and developed against the controlling definition of the ideal model of the Southern belle (Cash). As will be shown, Mitchell does encourage the breaking of the canon of bellehood by promoting resistance to the ideals of purity and beauty that are usually connected with the trope of white Southern femininity. She does so by choosing to conflict "different definitions of Southern women" (Jones 314) and by portraying Scarlett as someone who was not beautiful. This study, however, will also look at the possible rewards that can be reaped from such focus on female ugliness. Ultimately, taking into consideration John Berger's famous explanation that the male gaze sums up the implicitly gendered power dynamic of spectatorship in art will help us measure how, and if, Gone With the Wind undermines the social construction of visual pleasure as a male prerogative.

\section{Looking at Scarlett (Looking): Reconsidering Female Beauty}

8 “Scarlett O'Hara was not beautiful, but..." (Mitchell 3). If the initial stance on Scarlett does seem to liberate her from considerations of beauty, quickly enough a "but" is inserted in the text-"but men seldom realized it when caught by her charm," as if the narrator felt the urge to filter out from Mitchell's novel whatever wouldn't fit with the readers' expectations (or imagination) of the feminine ideal of the Southern belle, namely the very possibility of her ugliness. By reminding Mitchell's readers that Scarlett's ugliness is able to pass unnoticed, the novel highlights that those who look at Scarlett may be aesthetically fooled. Yet, the final part of the sentence, by providing explanation to the men's blindness, reinforces, if only indirectly, Scarlett's unsightliness by linking her to the Medusa figure. If Scarlett's appearance certainly does not evoke the Medusa-like qualities of the ugly women found in Welty's novels for instance, central however to the Medusan theme of petrifaction is the "idea of the viewer being caught as well as the intersubjective dimension to this encounter" (Miller 70).

9 All things/ugliness considered, one can wonder whether the text is truly liberating Scarlett from considerations of beauty. The first paragraph actually reads as an exercise of inspection into a woman's flaws:

In her face were too sharply blended the delicate features of her mother, a Coast aristocrat of French descent, and the heavy ones of her florid Irish father. But it was an arresting face, pointed of chin, square of jaw. Her eyes were pale green without a touch of hazel, starred with bristly black lashes and slightly tilted at the ends. Above them, her thick black brows slanted upward, cutting a startling oblique line in her magnolia-white skin-that skin so prized by Southern women and so carefully guarded with bonnets, veils and mittens against hot Georgia suns. (3) ${ }^{3}$

While we don't know for sure whether the narrator is male or female, the least we can say is that the initial portrayal of Scarlett reads as the product of male-dominated image-making. The novel exposes the female body in ways that conform to the dominant male gaze (Mulvey), i.e. to the "long history of grading aesthetics on a gendered curve" (Loofbourow).

11 The consequences on the reading experience are not to be understated. Loofbourow decries these as "nefarious," "poisonous," for "when you look at a face you've been told 
is female, you critique it at a much higher resolution than you do that same face if it's labeled male" ("The Male Glance"). The opening paragraph shows well how Scarlett's face is inspected with a magnifying glass. Surely enough, this exercise, as Loofbourow reminds us, is a "dominance exercise," since this practice "flatters the observer's opinion of his own perspicacity. He comes away convinced that, despite makeup and lighting [in Scarlett's case, despite her charm], he's seen through her attempt at deception and remained unaffected by it."

12 A cursory look at what has been written on the subject of the gaze reveals major differences: one school of criticism, influenced by Laura Mulvey's seminal essay “Visual Pleasure and the Narrative Cinema" (1975), contends that a traditional narrative text (cinematic or written) constructs men as gazing subjects while women are "looked at and displayed, with their appearance coded for strong visual and erotic impact" (11). Central to the masculine erotic pleasure as defined by Mulvey is the "woman as representation/image" (11): "in a world ordered by sexual imbalance, sexual pleasure in looking has been split between active/male and passive/female" (11). Simone de Beauvoir (1949) phrases this paradox in similar terms, when she claims that a woman is "often defined by the male gaze, construct, and desire. She becomes the sex object in a patriarchal society" (qtd. in Roy 26).

Since the 1970s, the model of analysis proposed by Mulvey and her followers have sparked much discussion, with the concept often being applied to both literature and art, thus expanding past the scope of just film theory. Another school of criticism, refusing Mulvey's deterministic model, has encouraged instead a resistant interpretation to the (all powerful) male gaze. Such critics wish to acknowledge and celebrate the "diverse ways in which women could subvert, redirect, or undermine the male gaze" (Stam 175). ${ }^{4}$

When it comes to analyzing the experience of spectatorship/readership in Gone with the Wind, such a multiplicity of critical approaches alerts us not to look for straightforward answers to the question of whether our pleasure in "looking" at Scarlett derives from Mitchell's manipulation of the masculine reader/spectator's visual pleasure ${ }^{5}$ or from Mitchell's resistance to Mulvey's patriarchal visual economy.

\section{Scarlett's looking, Scarlett's looked-at-edness}

On the surface, Gone With the Wind builds on gendered visual relations that seem to correspond to the traditional stance on female spectacle, with women being offered for aesthetic enjoyment and looked-at-edness (Mulvey). Looking at the female gender is indeed a crucial component of Mitchell's novel. Scarlett is the center of curiosity, jealousy, admiration, and she knows it well. On numerous occasions, she is described as catching a glimpse of Rhett's gaze on her. Scarlett, we learn,

still felt unclothed every time his [Rhett's] eyes ran up and down her figure. It was not that he ever said anything. Then she could have scorched him with hot words. It was the bold way his eyes looked out of his swarthy face with a displeasing air of insolence, as if all women were his property to be enjoyed in his own good time (308).

16 Scarlett not only comes in the narrative foreground as the vehicle of looking, ${ }^{6}$ but also as the object of the gaze. Her green eyes, her face, her "breasts, pushed high by her stays" (105), her 17-inch waist-line (3) are never dissociated from considerations of beauty (nor of measurement for that matter). ${ }^{7}$ This contributes to reinforcing rather 
than questioning the traditional stance on womanhood and even reads as an excuse for the initial blindness of the males looking on Scarlett-as if the text were trying to reestablish the traditional separation between men as gazing subjects and women as objects of looked-at-ed-ness. ${ }^{8}$

Even if this treatment is not exclusively reserved to Scarlett, in her case, we know that her green eyes are "turbulent, willful, lustful with life" (3-4), hers is "an arresting face, pointed of chin, square of jaw" (3), her breasts are indeed "very nice breasts" (105) and it is a pity that her legs "could not be shown" because "she had such nice legs" (105). "As for her waist," the narrator says, "no one [...] had so small a waist" (105). The narrator morselizes the heroine's own body, using here what Fredrickson and Robert have defined as a typical tool for women's sexual objectification. The text also draws attention to the heroine's looks as mirrored in the remarks of those belles who gaze at Scarlett, those "nasty girls who were so jealous" of her" (169), resorting here to what Naomi Wolf reads as a patriarchal device ("The Beauty Myth") through which women become their own worst enemies (122). Hustvedt calls this type of female gaze an "automatic adopting of [...] the male universal gaze." When women adopt the position of the universal male gaze, Hustvedt continues, they become complicit in its gendered power dynamics.

On numerous occasions Scarlett herself resorts to this position, suggesting that she ultimately conforms to the very conventions that she rejects and, to take up the words of Edward Snow, "become[s] an unwitting agent of the very forces of surveillance [she] wishes to oppose" (32). She is shown looking anxiously at herself in the mirror, checking her looks, policing herself (to use Wolf's terminology), and finding satisfaction in this "I" that she imagines reflected and sanctioned positively in the "eye" of those who would judge whether she looks pretty or not. Chapter 34 is particularly telling. In front of her mirror, Scarlett finds satisfaction in the way she looks:

How pretty she looked! The cock feathers gave her a dashing air and the dull-green velvet of the bonnet made her eyes startlingly bright, almost emerald colored. And the dress was incomparable, so rich and handsome looking and yet so dignified! It was wonderful to have a lovely dress again. It was so nice to know that she looked pretty and provocative, and she impulsively bent forward and kissed her reflection in the mirror and then laughed at her own foolishness (537).

19 Here, "looking" is repeated three times and "being pretty or nice" is repeated 4 times over a passage of 5 lines only, thereby highlighting how a woman's show is performedin this instance, flipping the expected male gaze (of the viewer/gazer) to a female gaze. In such moments, and to use the selfie terminology cited by McGill, Scarlett's engagement with the image of herself "offers a chink in the armour of the male gaze dominance, a crack where the light of the female gaze seeps through." If as Griselda Pollock puts it, visual representation reads as a site of privilege, then here Scarlett's fascination with the image of herself disrupts this privilege.

Certainly, here, two opposite readings of Scarlett's parading self may be envisioned: such a scene-if we are to use Mezei's terms-could be interpreted as one that "function[s] to gender looking as a feminine [rather than masculine] activity" (26). ${ }^{9}$ In other words, one may claim that "Scarlett's self-admiring reflection [certainly] is the triumph of literally made up femininity" (Young 250) - what Joan Rivière's pivotal essay defines as “Womanliness as Masquerade" (1929). Isn't narcissism, after all, the "fundamental attitude of all women?" (Beauvoir 654). 
Beauvoir asserts that what may appear as a narcissistic behavior in women is in fact a response to the "limitations and demands of femininity, demands and limitations which direct women's energy towards the body, the self, a terrain over which she has primacy and control" (qtd. in McGill). Here it is the notion of control that seems to be an integral part of Scarlett's appeal to look at herself in the mirror. In other words, the power and pleasure that Scarlett derives from her relationship with the image of herself allows her to represent herself as she wishes to be seen. Laura Mulvey describes this women's experience in her analysis of the male gaze: "It is always possible that the female spectator may find herself so out of key with the pleasure on offer, with its 'masculinization,' that the spell of fascination is broken," she writes. "On the other hand, she may not. She may find herself secretly, unconsciously almost, enjoying the freedom of action and control over the diegetic world that identification with a hero provides" ("Afterthoughts" 29, qtd. in Loofbourow).

\section{Female (in)visibility as a site/sight of anxiety}

Scarlett's gaze, however, is neither assertive nor combative, but instead passive, because exclusively focused on herself. This passivity is expressed linguistically in the narrator's purposefully not positioning her as a grammatical subject in the passage previously quoted where Scarlett is at her mirror: "The cock feathers gave her a dashing air and the dull-green velvet of the bonnet made her eyes startlingly bright, almost emerald colored. And the dress was incomparable." (537, my emphasis) Because Scarlett's looks confirm rather than upset (those who would/could look), ${ }^{10}$ her fascination with her own image bolsters the idea that the female gaze remains a force that must be contained, thereby anticipating Craft-Fairchild's argument that women's self-transformations are acceptable only to the extent that they serve to refocus the male gaze upon a consciously constructed image of femininity (830).

As a result, Scarlett's repeated resort to this female masquerade (validated by her fetish object, the mirror) can be envisioned not as a way to flout convention by representing herself publicly in her own terms, but rather as a way "to participate in man's desire" (Irigaray 133). Such a reading is confirmed by Scarlett's own self-awareness of the dynamics and complexities of gazing (or surveillance). These offer a framework for evaluating the novel's power relationships that are in such instances rooted in gender. If at times indeed Scarlett is aware of her charm even before she sees confirmation in Rhett's eyes (336), more often than not, she manifests anxiety at not looking pretty:

She had glanced in the mirror every morning to see that her face was clean and her hair tidy but she had always been too pressed by other things to really see herself. But this stranger! Surely this thin hollow-cheeked woman couldn't be Scarlett O'Hara! Scarlett O'Hara had a pretty, coquettish, high-spirited face. This face at which she stared was not pretty at all and had none of the charm she remembered so well. It was white and strained and the black brows above slanting green eyes swooped up startlingly against the white skin like frightened bird's wings. There was a hard and hunted look about this face. (515)

Scarlett's vulnerability manifests itself as a deep anxiety at not recognizing or validating herself. In the above-quoted passage, Scarlett's awareness that she is a visual "object" is conveyed in the shift from the possessive "her face" to the indefinite demonstrative "this" ("this face") and the final neutral "it." The narrator's own admission that the reflection of this stranger, this thin-hollow cheeked woman, is 
severed from Scarlett O'Hara reminds us that to be culturally intelligible as a Southern belle/ideal female requires embodying visual signs. It means wrestling with what de Beauvoir termed the eternal feminine, the mythology of femininity which women were expected to absorb as if it were their own flesh. Failing to do so, Beauvoir explains, is well documented: witches, crones, spinsters, the ugly bitch (qtd. in McGill). ${ }^{11}$

In this instance, the failure is traced at the narrative level, with the narrator eliminating the "she" as a subject-pronoun in the first sentence to privilege instead the indefinite "this face", "this stranger" or "the white skin." By aligning Scarlett's identity with no more than a look, the narrator suggests Scarlett's own fear of rejection. This explicit positioning of female (in)visibility as a site/sight of anxiety recognizes and seemingly confirms John Berger's idea:

Men act and women appear. Men look at women. Women watch themselves being looked at. This determines not only most relations between men and women but also the relation of women to themselves. The surveyor of woman in herself is male: the surveyed is female. Thus, she turns herself into an object of vision: a sight (47).

But Mitchell, aware that vision is "the sense best adapted to express dehumanization" (Scheman 153), refuses to reduce the characterization of Scarlett to her manipulation of Southern signifiers of gender.

\section{Vision, Knowledge, and Power}

There is more to explore in Mitchell's novel than just a performative/ugly/noncompliant Southern belle and blind Southern beaux; more than just passive/objectified female bodies and active/empowered males. What I call the library scene shows well that Scarlet is more than a face whose deception the narrator has sought to expose.

\section{The auditory vs. the visual: the power of eavesdropping}

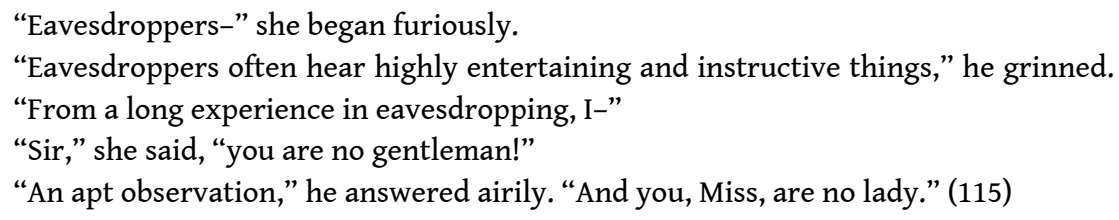

That it should be Rhett Butler-placed as an eavesdropper in this scene-who exposes and complicates the trope of the classic, all too beautiful, and untouchable Southern belle is important for several reasons: not only does Rhett appear as an excellent reader of Scarlett, but he is also one who attempts to reach beyond a purely conventional feminine surface. In his imagination, Scarlett cannot and should not be constrained by the formula of Southern bellehood. For Scarlett, on the other hand, who thought she had escaped surveillance by sneaking into the library (a male space par excellence) to declare her love to Ashley Wilkes, she can only be aware that she has been exposed as wearing a mask-that of the Southern lady. Being pushed off her pedestal reads as a punishment of the Southern belle for transgressing the physical boundaries into a male space and the margins imposed to womanhood. With his "you're no lady," Rhett shares the narrator's perspicacity made obvious from the opening paragraph of the novel.

Yet, such a judgment is linked to the complex relationship between what can be seen and what can be known, which is integral to the issue of identity formation at the core of the novel. If seeing Scarlett seems to provide a great amount of easily categorized 
and categorizable information (the narrator is assertive: she is "not beautiful" (3)), on numerous occasions also, the text interrogates the very possibility of ever knowing Scarlett or any Southern belle for that matter. After all, if the text initially suggests that Scarlett's physical features might be pinned down, it also intimates that the analytical stance on Scarlett will invariably fail, since the gazing subject, in this case the men, does not see well. As India (Ashley Wilkes' sister and rival of Scarlett) admits, Yankees, like most Southern men, "don't know that you [Scarlett] aren't one of us and have never been. Yankees haven't sense enough to know that you haven't any gentility" (757). In doing so, Mitchell facilitates a feminist reading of Gone With the Wind by encouraging a specific discourse of resistance to, and redirection and interrogation of, the male gaze. If indeed, as Peter Middleton argues, the male gaze is the one which "triangulates vision, knowledge, and power" (qtd. in Schehr 29), Mitchell does seem ready to complicate this traditional equation: if men see, men do not know.

Mitchell intimates that instead of congratulating themselves on their perfect vision, men will know only when-and if-they rely on other means (in the library scene, the auditory) to notice that under the mask lurks an intentional subjectivity. For Horstkotte indeed, the auditory allows to "reconceptualize vision as an exchange between the subject and object of perception, and accord equal importance, and what is more, agency, to both parties" (4). In this dynamic, "[n]o longer is the spectator supreme subject and master of that which $\mathrm{s} / \mathrm{he}$ sees, nor is the object a passive recipient of that gaze" (4). Considering how Rhett and Scarlett both use the auditory to exert force on each other and the world around them, the gendering of senses becomes an obvious lens for examining the power dynamics at work in Gone With the Wind.

31 Mitchell further interrogates the traditional equation between vision, knowledge, and power by showing that it is often the active female gaze (like India's) that actually triangulate vision, knowledge, and power in the novel. In Gone With the Wind, we do see Middleton's theory come to fruition, albeit in a reversed and complexified manner: the triangle vision, knowledge, and power is exemplified not solely in the men looking at Scarlett, but in the women (and the narrator) looking at her.

Right after the library scene in which she has declared her love to Ashley, the humiliated Scarlett decides to return to the bedroom in which the other young belles are taking their beauty naps. When slipping back into the room, Scarlett hears them overtly criticizing her unladylike behavior that afternoon at the Oaks Plantation. In this episode, Scarlett becomes both the object of conversation and the agent of overhearing. This scene serves a double purpose. First, it challenges Scarlett's position as the sole object of vision and aesthetic enjoyment. The gaze as an instrument of vision and knowledge is disavowed: Scarlett has escaped surveillance-physically, by sneaking out of the bedroom, and also symbolically, when she is turned into an eavesdropper, one who, by definition, escapes the gaze to rely on hearing to acquire knowledge and power.

In the protected space of domesticity (the only space deemed proper to these belles-tobe), the girls are overheard stripping away the veneer of Scarlett. Scarlett, they say, "acted as fast as a girl could act to-day" (117) because "all Scarlett O'Hara has ever done has been to stir up trouble and try to get other girls' beaux" (118). In this episode, Mitchell's narrator seems to suggest that if men do fail to realize that Scarlett "was not beautiful" (3) and if Scarlett's tricks "never failed to convince foolish males of her sweetness and unselfishness" (117), these young belles see through the mask. Here 
Mitchell complicates the traditional imperial and patriarchal gaze by questioning the traditional equation of "the gaze" with heteronormative white patriarchy. Mitchell detaches knowledge from vision and masculinity from power (men are indeed foolish). To use Ford's terms, the act of eavesdropping, because it reveals the knowledgeable female gaze on Scarlett, is "subordinating the "male gaze" to being [just] one look amongst many" (154). In order to get a clear picture of Scarlett-that is, to triangulate vision, power, and knowledge-not only should the (failing) male gaze be registered but the female gaze as well. Mitchell, in a sense, uses focalization on Scarlett against itself to prove the inconsistency and fragility of the male gaze. The resulting effect is one of heteroglossia.

\section{Heteroglossia and "heteroscopia"}

The female viewing positions offered by the Southern belles suggest multiple perspectives on Southern femininity. And in such instances, instead of providing a conventional vision of gendered relations in the South that would support an either/or; female/male; active/passive dichotomy, the narration refuses to privilege one performance over another. Instead it promotes multiple perspectives on Scarlett, thus offering a "both/and" vision of womanhood. ${ }^{12}$ To say it with Laurie Finke, whose contextualization of Bakhtin's notion of heteroglossia proves relevant here, "if patriarchy has created the illusion of monologic utterances monopolized by men, then feminists can dispel that illusion by appropriating the notion of heteroglossia, highlighting the dialogic nature of all discourse, insisting that those contested voices be heard" (14).

When men are blind to the real Scarlett, the narrator intimates that they'd better consider multiple other perspectives. A case in point is the porch scene that features the Tarleton twins trying to assign meaning to Scarlett's quietness or her looking sick. What bothers them is what lies beyond appearances. If the twins assert that they know Scarlett well (their certitude is conveyed through assertive sentences like, "when Scarlett gets mad, everybody knows it" and "Scarlett don't set any more store by book learning than we do" (11)), the text works against the masculine gaze to disavow the position of knowledge initially defended by the twins: who/what stands before their eyes is not so clear anymore. Once again, connection between signification and body is problematized as Mitchell dramatically complicates the image of Scarlett as a signifying field. The twins wonder:

"It looked to me like she was mighty glad to see us when we came."

"I thought so, too."

"And then, about a half-hour ago, she got kind of quiet, like she had a headache."

"I noticed that but I didn't pay it any mind then. What do you suppose ailed her?"

"I dunno. Do you suppose we said something that made her mad?"

They both thought for a minute.

"I can't think of anything. Besides, when Scarlett gets mad, everybody knows it. She don't hold herself in like some girls do."

"Yes, that's what I like about her. She don't go around being cold and hateful when she's mad-she tells you about it. But it was something we did or said that made her shut up talking and look sort of sick. I could swear she was glad to see us when we came and was aiming to ask us to supper."

"You don't suppose it's because we got expelled?"

"Hell, no! Don't be a fool. She laughed like everything when we told her about it. And besides Scarlett don't set any more store by book learning than we do" (11). 
surface, at least, one could assert that the porch scene abides by the dichotomy between what Silverman reads as "women's lack, specularity, and (diegetic) containment" as opposed to male "potency, vision, and (diegetic) exteriority" (1988 149). If the passage reads as a brilliant exercise in how men, through history, have reassured themselves by narrating women as sentimental, melodramatic, moody, or confessional (Irigaray), male potency and vision are disavowed one more time, since Scarlett, in this scene, defies (clear) interpretation. ${ }^{13}$

The fact is that the twins, while congratulating themselves on their insight, cannot make sense of Scarlett. While claiming they are no fools, they are fooled by Scarlett, unable to seek detail into a woman's intentions. And it is so because theirs is not so much a reading as it is a (cursory) looking at Scarlett. Lili Loofbourow's meditation on the difference between the two aesthetic paradigms is worth repeating:

The danger of the male glance is that it is reasonable. It's not always or necessarily incorrect. But it is dangerous because it looks and thinks it reads. The glance sees little in women-centric stories besides cheap sentiment or its opposite [...] The male glance is the opposite of the male gaze. Rather than linger lovingly on the parts it wants most to penetrate, it looks, assumes, and moves on. It is, above all else, quick. ("The Male Glance")

Unsurprisingly maybe, the initial line in the twins' dialogue ("it looked to me") may be said to contradict what the twins claim to be doing, with the use of an impersonal turn of phrase depriving them of any actual agency in the process of "looking." In their distant diagnostic speed, the twins have become, to use Loofbourow's terminology, "closer to the amateur astronomer than to the explorer."

As a consequence, Mitchell suggests that they will need to resort to other gazes if they wish to interpret why Scarlett has acted so strangely upon hearing the news of Ashley's engagement to Melanie. Referring to "that black grapevine system which defies white understanding" and presenting the "darkies" as spies who "know everything that goes on," the narration has the twins rely on Jeems, their black slave, to understand what the matter is with the belle. Rather than an all-powerful male or imperial gaze, Mitchell, in this scene, constructs what could be regarded as mutual gazing. As Klaver explains, in such instance: "traditionally subjected characters (the slaves) look back, stereotypes are challenged (with the center of knowledge being displaced) and the gaze (with its inherent anxieties and domination,) becomes a mutual [rather than exclusive and domineering] process of looking" (qtd. in Howell et Al. 12). The idea of the gaze as phallocentric, domineering, and patriarchal is thus complicated, since through eavesdropping again, Gone With the Wind admits to "a third knowledge system into [its] lexicon" and stresses "the importance of exploring unofficial information systems [precisely the black grapevine system] that have been subjugated to nominally "higher" ways of knowing" (Yaeger 111).

Once more, eavesdropping becomes an instrument of complexification of, and resistance to, the knowledgeable-yet, all too quick-male gaze/glance, a mechanism of subversion that serves a deconstructive goal: the narrowness of what women like India identify as the masculine glance/gaze is counterbalanced by the broader, and more relevant, vision of these marginalized (black slaves' and women's) perspectives, reminiscent of Michael Bakhtin's notion of polyphony. ${ }^{14}$ Polyvocality (achieved by having a narrator report what a character has heard another character say that another character has said) is a recurrent textual medium throughout-one that

Transatlantica, 1 | 2019 
permits a reconsideration of critical assumptions of gendered "essentialism." So doing, the narrative uncovers possibilities for alternative forms of focalization which do not operate within the firm (gendered) boundaries of the male gaze and the objectified female.

\section{Alternative forms of focalization. Alternative forms of vision}

41 Although Gone With the Wind repeatedly represents the white male characters as the dominant gazing subjects (the center of attention being Scarlett), male characters, unexpectedly perhaps, are also positioned as the looked-at objects. Like women, men, we realize, are never shielded from intense observation either. Describing the Tarleton twins as "long of bone and hard of muscle," Mitchell has them lounging "lazily in their chairs," laughing with "their long legs, booted to the knee and thick with saddle muscles, crossed negligently." (4) The scene here contains potential radical reversals: even though one cannot ascertain whether the twins are looked at by a female character, the scene suggests, indeed through the twins, what Silverman (1992) has defined as the impossibility of ever fully owning the gaze (the twins are observed as much as they observe) and the impossibility of escaping specularity.

When they are not objects of the gaze, the twins are often used as vehicles of looking, as the central consciousness through which ideas about Southern white masculine subjectivity is transmitted. As we have seen (and much like the narrator in the opening paragraph), the twins provide glasses through which one should imagine Scarlett, or Southern belles for that matter, for the rest of the story: glad, mad, cold, hateful, etc. On multiple occasions, the twins also provide Mitchell's readers with masculine looking-glasses through which one quickly understands the definition of white masculinity in Clayton County, Georgia: "raising good cotton, riding well, shooting straight, dancing lightly, squiring the ladies with elegance and carrying one's liquor like a gentleman were the things that mattered" (5). The twins who "excel" in these "accomplishments" (5) give evidence to some of the values held in high esteem for Southern gentlemen-honor, strength, duty, among others. In their gender-coded society, the twins testify to the existence of a model of hegemonic (understand "acceptable") masculinity.

Certainly, there are ways in which men like Able Wynder, for instance, uphold the hegemonic model. In the twins' classification, Able Wynder, though poor, is regarded as a "real man" because "the best shot in the Troop" (24). As for Ashley Wilkes, "born of a line of men who used their leisure for thinking, not doing, for spinning brightly colored dreams that had in them no touch of reality" (35), he is much too feminine. Seen through the lens of the Tarleton twins, the pure-blooded Ashley, yet about to marry a plain and gentle lady from Atlanta, does not fit their definition of masculinity. The opening of the novel purposefully confuses the definition of the gentleman by granting gentility title to the best shot in the troop yet severing noble blood from gentility entitlement, here, from the one who is "kind of queer about music and books and scenery" (22): Able Wynder is not a gentleman, yet is regarded as the epitome of white Southern manhood. Ashley Wilkes is from gentleman-stock, yet not a "real" man.

The critical lens offered by the twins is certainly pleasant because it (hastily) organizes, labels, and confirms. The observations they make is what Loofbourow reads as "the 
male glance's sub rosa work [...] it feeds an inchoate, almost erotic hunger to know without attending-to omnisciently not-attend, to reject without taking the trouble of analytical labor [...] Rather than investigate or discover, [they] point and classify."

There is, however, nothing more misleading and dangerous than hasty categorization. If we thus categorize, Rhett would certainly (unlike Ashley) appear as the epitome of male dominance and superiority and it would even be tempting to reduce the characterization of Rhett and Ashley to a representation of stark binary oppositesAshley, the "studious country gentleman" (212), wears a "faded, patched uniform" (365) and his "blond hair bleached by summer suns" (365) makes him "pale" in contrast to Rhett, who is "dark of face, swarthy as a pirate [...] [whose] eyes were as bold and black as any pirate's appraising a galleon to be scuttled or a maiden to be ravished" (135). The novel does take great pain to place Ashley in a disempowered position, to label him as ordinary, and by contrast, to present Rhett as out of the ordinary.

While on the surface there is much that separates the two men, a more complex representation of white Southern masculinity emerges. One such complication is evident in the (multiple and often morselized) making and reception of Rhett Butler. Rhett is indeed presented as a "dashing figure" who "spent money freely, rode a wild black stallion, and wore clothes which were always the height of style and tailoring." He becomes the center of attention everywhere he goes, one "that people turned to look at" (308). There is "something breathtaking in the grace of his big body," the narration notes, "which made his very entrance into a room like an abrupt physical impact, something in the impertinence and bland mockery of his dark eyes that challenged her spirit to subdue him" (306). Aunt Pitty, in particular, feels the strong hold of Rhett's "complete masculinity" (306). As the novel progresses, and as the above quotes reveal, the text tends to place greater importance on what women (like Aunt Pitty) feel, not only look at.

There is more to explore than just Rhett as a "big body," however: portrayed as a heartless brute, as a blockade runner interested in money, he is also depicted as a protecting and loving father by the very "women who had heretofore believed that no woman was safe with him [...] Even the strictest old ladies felt that a man who could discuss the ailments and problems of childhood as well as he did could not be altogether bad" (1276). Melanie even feels "indignation at what she fancied was a gross injustice done to him" (307). Through different accounts, different eyes, interpreted by Melanie, Scarlett, and numerous other female spectators, Rhett unsettles definition and complicates the Southern beau-centered model of (un)acceptable masculinity.

While accounts of Rhett's rebellion against the traditional values and models of the old South provide a neat explanation of how and why he stands apart from his fellow Southern men, Mitchell suggests that reading manhood and masculine beauty or ordinariness (much like considering Scarlett's ugliness or beauty) should not be a hasty or lazy exercise. When we mistake cover-up for content, the risk is that we may think "we're seeing clearly when [...] we're dreadfully, cataclysmically myopic" (Loofbourow).

The irony, of course, is that Scarlett learns this lesson the hard way. Even though Scarlett (like other female observers) is repeatedly called upon to look acceptingly at male lack, in Ashley's case, "to acknowledge and embrace male castration" (Silverman, 1992 69), ${ }^{15}$ it does take more than 900 pages before Scarlett realizes that she had "made him wear [pretty clothes] whether it fitted him or not. And [she] wouldn't see what he really was" (940). Critics have repeatedly asked: what is it with Ashley that makes 
Scarlett so infatuated with him? Why can't she open her eyes and liberate him from this beauty that she considers makes his very essence? Ashley's wearing the costume of the Confederacy, Ashley as the abiding and patriotic soldier, is certainly at fault, and causes Scarlett's mistaken love, allowing him to remain shielded from man's lack and ordinariness (at least in Scarlett's eyes).

That Ashley, the Southern gentleman, should remain almost spectral, impalpable, and incommunicable should not come as a surprise. Indeed, much work on white hegemonic masculinity takes it as a starting point that hegemonic masculinity and whiteness have retained their powers as signifiers and normative practices because they are invisible (see for example, Gros 176). As Sally Robinson explains, the argument goes "one cannot question, let alone dismantle, what remains invisible from view" (1). Starting from this premise, one could certainly argue that Ashley Wilkes has endured as the epitome of the Southern gentleman because of Scarlett's (and the readers') own blindness at Ashley's ugliness/ordinariness. ${ }^{16}$ To say it with Loofbourow, this reduces to a fairly simple proposition: we can't see complexity in the Southern gentlemen's stories because we have so little experience imagining it might be there. Put differently, once you have internalized that expectation of what it is you're watching, it's hard to resist the hints the packaging offers, hard to see beyond the Southern beau versus the Southern rogue chasm, hard to imagine equivocations and ambivalences. ${ }^{17}$

\section{Concluding Remarks}

This article has started with the realization that our visual experience of Scarlett is shaped by the beauty myth. By examining the power dynamics in the novel, one may safely argue that Mitchell is asking her readers to explore the female body from multiple angles: she uses the white female body in ways that conform to the prototypical Southern romance. At the same time, she undermines attempts to preserve the Southern belle's standards of behavior.

52 Going beyond the scholarly tradition of solely critiquing the patriarchal discourse of female beauty/ugliness, this article has also shown that if the critical discomfort with Mitchell's construction of white masculinity certainly results from a problematic (because ineffectual) representation of manhood-that is, from the depiction of Southern beaux "gone wrong" or "gone ugly"-Mitchell's readers also need to take into account what I consider here as a failure or a refusal-on the writer's part-to offer or imagine a focalized and privileged "masculine" perspective in the text. Through the prerogatives of vision, Mitchell's text demotes the alluring "authenticity" of the malecentered narrative-in particular, by complexifying and resisting the imperative position of a white masculine power/gaze.

This article concludes with the realization that our visual experience in Gone With the Wind is essentially shaped by the objectivity myth-that someone somewhere might see it all and understand it all. Men are blind, the twins are blind, and Scarlett's own blindness, her failure to see Rhett Butler and the potential role he could play in her life, as well as her failure to realize that "Ashley never really existed at all, except in my imagination" (940) suggest that the cultural, historical, societal, and gendered norms we have been taught might indeed mislead us into not so "apt [an] observation," to quote Rhett Butler. There might also be a cost to the textual directions we receive in 
the opening paragraph of a classic like Gone With the Wind. Often indeed, a failure of imagination, Mitchell suggests, can actually produce a failure of vision.

\section{BIBLIOGRAPHY}

BERGER, John. Ways of Seeing. London: British Broadcasting, 1973.

BLOOM, James D. Reading the Male Gaze in Literature and Culture: Studies in Erotic Epistemology.

London: Palgrave Macmillan, 2017.

BOOT, Max. "Furling the Confederate Flag is Just the Start." Commentary. 22 June 2015. https:// www.commentarymagazine.com/max-boot/let-the-confederate-flag-come-down/ Accessed 2 July 2020.

BUTLER, Judith. "Performative Acts and Gender Constitution: An Essay in Phenomenology and Feminist Theory." Theatre Journal, vol. 40, no. 4, 1988, p. 519-531.

CASH, W. J. The Mind of the South. 1941. New York: Vintage, 1991.

CLINTON, Catherine and Nina Silber. Divided Houses: Gender and the Civil War. New York: Oxford University Press, 1992.

CRAFT-FAIRCHILD, Catherine. Masquerade and Gender: Disguise and Female Identity in EighteenthCentury Fictions by Women. University Park: Pennsylvania State University Press, 1993.

CRANK, James A., ed. New Approaches to Gone with the Wind. Baton Rouge: Louisiana State University Press, 2016.

DE BEAUVOIR, Simone. The Second Sex. 1949. Translated from the French by H. M. Parshley, Penguin 1972, New York: Vintage Books, 1974, 2011.

DOANE, Mary Ann. "Film and the Masquerade: Theorising the Female Spectator." Screen, vol. 23, no. 3-4, 1982, p. 74-87. Accessed 6 December 2018.

DU BOIS, W.E.B. The Souls of Black Folks. 1903. New York: Pocket Books, 2005.

ENTZMINGER, Betina. The Belle Gone Bad: White Southern Women Writers and the Dark Seductress. Baton Rouge: Louisiana State University Press, 2002.

FEUERHERD, Peter. “The Dangers of Gone with The Wind's Romantic Vision of the Old South.” Jstor Daily. 8 Nov. 2017. https://daily.jstor.org/the-dangers-of-gone-with-the-winds-romantic-visionof-the-old-south. Accessed 6 December 2018.

FINKE, Laurie A. Feminist Theory, Women's Writing. Ithaca: Cornell University Press, 1992.

FORD, Susan. "Landscape Revisited: A Feminist Reappraisal." New Words: New Worlds. Reconceptualizing Social and Cultural Geography. Ed. C. Philo. Lampeter: St David's University College, 1991, p. 151-55.

FOX-GENOVESE, Elizabeth. "Scarlett O'Hara: The Southern Lady as New Woman.” American Quarterly, vol. 33, no. 4, 1981, p. 391-411. 
FREDRICKSON, Barbara L. and Tomi-Ann ROBERTS. "Objectification Theory: Toward Understanding Women's Lived Experiences and Mental Health Risks." Psychology of Women Quarterly, vol. 21, no. 2, June 1997, p. 173-206.

GIRIDHARADAS, Anan. “A New Image of Female Authenticity.” The New York Times. 15 October 2013. nytimes.com/2013/10/15/us/a-new-image-of-female-authenticity.html. Accessed 5 December 2018.

GROS, Emmeline. "Hiding in Plain Sight: The Vanishing Male Figure in Gone with the Wind." Dixie Matters: New Perspectives on Southern Femininities and Masculinities. Studies in Literature and Culture. Ed. Urszula Niewiadomska-Flis. Lublin: Wydawnictwo KUL, vol. 10, 2013, p. 173-95.

HASKELL, Molly. “Gone, but not forgotten,” The Guardian. 13 May 2009. www.theguardian.com/ film/2009/may/13/gone-with-the-wind. Accessed 3 December 2018.

HORSTKOTTE, Silke and Karin LEONHARD. Seeing Perception. Newcastle, UK: Cambridge Scholars Pub., 2007.

HOWELL, L., R. RICKEY and M. KLAVER. "Peripheral Visions." Rev. of E. Ann Kaplan, Looking for the Other: Feminism, Film, and the Imperial Gaze. New York: Routledge, 1996. pmc.iath.virginia.edu/textonly/issue.198/8.2.r_klaver-et-al. Accessed 7 January 2015.

HUSTVEDT, Siri. A Woman Looking at Men Looking at Women: Essays on Art, Sex, and the Mind. New York: Simon \& Schuster Paperbacks, 2016.

IRIGARAY, Luce. This Sex Which Is Not One. Ithaca: Cornell University Press, 1985.

JERNG, Mark C. "Reconstructions of Racial Perception: Margaret Mitchell's and Frank Yerby's Plantation Romances." New Approaches to Gone with the Wind. Ed. James A. Crank. Baton Rouge: Louisiana State University Press, 2016, p. 38-65.

JONES, Anne Goodwyn. Tomorrow Is Another Day. Baton Rouge: Louisiana State University Press, 1981.

LEITH, William. "The Ugly, Unfair Truth about Looking Beautiful.” The Telegraph, Telegraph Media Group. 16 Sept. 2013. www.telegraph.co.uk/women/womens-life/10302408/The-uglyunfair-truth-about-looking-beautiful.html Accessed 10 June 2020.

LOOFBOUROW, Lili. “The Male Glance.” VQR Online, 2018. www.vqronline.org/essays-articles/ 2018/03/male-glance. Accessed 10 June 2020.

LORECK, Janice. "Explainer: What Does the 'Male Gaze' Mean, and What About a Female Gaze?" The Conversation. 5 January 2016. theconversation.com/explainer-what-does-the-male-gazemean-and-what-about-a-female-gaze-52486/. Accessed 27 December 2018.

MCGILL, Mary. "How the Light Gets In: Notes on the Female Gaze and Selfie Culture." MAI: Feminism \& Visual Culture. 1 May 2018. maifeminism.com/how-the-light-gets-in-notes-on-thefemale-gaze-and-selfie-culture/. Accessed 6 December 2018.

MEZEI, Kathy. Ambiguous Discourse: Feminist Narratology and British Women Writers. Chapel Hill, NC: University of North Carolina, 1996.

MIDDLETON, Peter. The Inward Gaze: Masculinity and Subjectivity in Modern Culture. London: Routledge, 1992.

MILLER, Monica C. Being Ugly: Southern Women Writers and Social Rebellion. Baton Rouge: Louisiana State University Press, 2017.

MITCHELL, Margaret. Gone with the Wind. 1936. London: Pan MacMillan, 2008. 
MOORE, Tracy. “Will Women Ever Have the Freedom to Be Ugly?" Jezebel. 22 October 2013. jezebel.com/will-women-ever-have-the-freedom-to-be-ugly-1447984254. Accessed 5 December 2018.

MULVEY, Laura. "Visual Pleasure and Narrative Cinema." Screen, vol. 16, no. 3, 1975, p. 6-18. Accessed 5 December 2018.

MULVEY, Laura. "Afterthoughts on 'Visual Pleasure and Narrative Cinema' inspired by King Vidor's Duel in the Sun (1946)." Visual and Other Pleasures. Bloomington: Indiana University Press, 1989.

POLLOCK, Griselda. Vision and Difference: Femininity, Feminism and Histories of Art. London: Routledge. 1988.

PYRON, Darden Asbury. Southern Daughter: The Life of Margaret Mitchell. New York: Oxford University Press, 1991.

RIPLEY, Alexandra. Scarlett: The Sequel to Margaret Mitchell's Gone with the Wind. New York: Grand Central Publishing, 2011.

RIVIERE, Joan. “Womanliness as Masquerade.” International Journal of Psychoanalysis, vol. 10, 1929, p. 303-13.

ROY, Abhik. Selling Stereotypes: Images of Women in Indian Television Commercials. New Dehli: New Concept Information Systems, 1988.

RUSSELL, Gabrielle. “Women in Film-Scarlett O'Hara and Orlando: ‘This Is Your Life!”'Women, Power, and Resistance: An Introduction to Women's Studies. Ed. Tess Cosslett, Alison Easton, and Penny Summerfield. Buckingham: Open University Press, 1996, p. 113-25.

SACHSMAN, David B., S. Kittrell RUSHING, and Roy MORRIS. Memory and Myth: The Civil War in Fiction and Film from Uncle Tom's Cabin to Cold Mountain. West Lafayette: Purdue University Press, 2007.

SCHEHR, Lawrence R. Parts of an Andrology: On Representations of Men's Bodies. Stanford: Stanford University Press, 1997.

SCHEMAN, Naomi. Engenderings: Constructions of Knowledge, Authority, and Privilege. New York: Routledge, 1993.

SILVERMAN, Kaja. The Acoustic Mirror: The Female Voice in Psychoanalysis and Cinema. Bloomington: Indiana University Press, 1988.

SILVERMAN, Kaja. Male Subjectivity at the Margins. New York: Routledge, 1992.

SNOW, Edward. "Theorizing the Male Gaze: Some Problems." Representations, no. 25, 1989, p. 30-41.

STAM, Robert. Film Theory: An Introduction. Malden: Blackwell Publishing, 2000.

SUNSTEIN, Cass R., "In Defense of Gone With The Wind." The Atlantic. 16 July 2015. www.theatlantic.com/politics/archive/2015/07/gone-with-the-wind-confederacy/398663/. Accessed 5 December 2018.

TAYLOR, Helen. Scarlett's Women: "Gone With the Wind" and its Female Fans. London: Virago Press, 2014.

THE OBSERVER. "Vivien Leigh, the greatest beauty of her time, dies at 53." Vivien Leigh's Obituary, 9 July 1967. https://www.theguardian.com/theguardian/from-the-archive-blog/2013/ nov/05/vivien-leigh-anniversary-obituary-observer-1967/. Accessed 2 July 2020. 
WATKINS, Floyd C., “'Gone with the Wind' as Vulgar Literature.” The Southern Literary Journal, vol.

2, no. 2, 1970, p. 86-103.

WOLF, Naomi. The Beauty Myth: How Images of Beauty Are Used against Women. New York: W.

Morrow, 1991.

WOOLF, Virginia. A Room of One's Own. 1929. Penguin Classics, 2002.

YAEGER, Patricia. Dirt and Desire: Reconstructing Southern Women's Writing, 1930-1990. Chicago: University of Chicago Press, 2000.

YOUNG, Elizabeth. Disarming the Nation: Women's Writing and the American Civil War. Chicago: University of Chicago Press, 1999.

\section{NOTES}

1. Interestingly, Scarlett is ready to be compliant, i.e. "to spend the time, money, and energy it takes to live up to a cultural beauty standard that says skin tones must be evened out, eyes must be enhanced, cheek bones accented, weight managed, desirability advertised" (Moore), but she is not ready to comply with the rewards usually reserved for such "ornamental" women (precisely that of being ornamental, living on a pedestal). This rebellion at the heart of Southern womanhood has been convincingly explored in the works of Entzminger, Fox-Genovese, or Miller more recently.

2. Scarlett's non-compliance, her ability to "slip past the boundaries of what is ideal and expected" (Miller 4) would even account for the incredible endurance of Gone With the Wind. Miller suggests that "Gone With the Wind remains popular, at least in part because of the ways in which it attempts to subvert these ideals through the deployment of ugly counterplots" (47).

3. The first sentence of this quotation certainly places Scarlett as a belle gone bad or born bad, because of her Irish features in particular.

4. Mulvey's concept of the "male gaze" is more accurately described as a heterosexual, masculine gaze (Loreck).

5. As Mulvey explains, however, the spectator does not necessarily need to be a "man." Mulvey argues that as viewers, we identify with the primarily male character in whom we recognize ourselves. Loreck summarizes best the "male gaze," which "suggests a sexualized way of looking that empowers men and objectifies women. In the male gaze, woman is visually positioned as an "object" of heterosexual male desire. Her feelings, thoughts and her own sexual drives are less important than her being "framed" by male desire."

6. In the movie also-and as Gabrielle Russell (1996) has remarked-"the film encourages spectator identification with Scarlett over every other character" because "we are shown her face more often, but crucially, we are physically brought closer to her, encouraging intimacy [...] we follow her every move, in fact, she is hardly out of our sight" (114). In these instances, "we see how the cinematic specificities of camera shot and editing operate in Gone With the Wind in conjunction with Scarlett's character, highlighting her as the most important object of our looking" (Russell 114).

7. Scarlett, of course, is not the only woman in this case. Focalization (by Scarlett) on other women also points to "Mrs. Meade with her bonnet askew and her arm through that of fifteenyear-old Phil; the Misses McLure trying to make their trembling upper lips cover their buck teeth; Mrs. Elsing, erect as a Spartan mother, betraying her inner turmoil only by the straggling gray locks that hung from her chignon; and Fanny Elsing white as a ghost" (242).

8. Naomi Wolf defines the "Beauty Myth" as "a violent backlash against feminism that uses images of female beauty as a political weapon against women's advancement" (9). A woman's 
value and power is tied to how attractive she is. For Wolf, this promise is false, a political weapon used against women to keep them in their place.

9. Looking is also often presented as a female activity in the novel, as Scarlett is found seeking refuge from the female interrogative gazes at Melanie's party (920) or reading into Mammy's "smouldering eyes" (537).

10. In this case, the female look is safely directed at herself (at her own mirror); Virginia Woolf reminds us that only when the female looks at her spectator, i.e. when she returns the gaze, upsets the accepted hierarchy of power, and expresses desires of her own, does she cease to be the passive mirror in which men see their greatness reflected (A Room of Own's Own 35).

11. It is not surprising that in a world ordered by the Southern lady who stands at the "core of a region's self-definition" (Jones 4), pleasure (or the absence thereof) in looking at the Southern belle becomes split into polarized images of the whore/virgin Mary. On one side of the spectrum, we find the Magdalen/liberated woman in the person of Belle Watling the prostitute and on the other hand, the Southern Belle/Mother of Christ figure embodied in the innocent Melanie or the self-sacrificing Ellen O'Hara (Clinton and Silber).

12. The enactment of this process is what Toril Moi calls "textual practice" in Virginia Woolf's texts (qtd. in Mezei 9).

13. On this subject, see Joan Rivière, "Womanliness as a Masquerade."

14. The motives are indeed multiple: women, Mitchell reveals, wish and do partake in the gaze, not only to detach gender from the reading eye/I, but also to detach the idea of dominance from masculinity itself.

15. Elizabeth Young, in Disarming the Nation: Women's Writing and the American Civil War, shows how Mitchell, while masculinizing Scarlett, has queered Ashley and offered an unconventional portrayal of manhood in her fiction: Charles Hamilton is portrayed as "a pretty, flushed boy" and Frank Kennedy compared to "an old maid with britches" (150). If we believe Young, Mitchell's reading audience may be clearly disappointed when finding that the truly feminine figures in Gone with the Wind are male and that Mitchell specifically "links the weakness of the Confederate body politic with the imagined impotence of male bodies" (2008 233). Logically also, and still according to Young, it is no surprise that the wartime newspapers mentioned in the novel should themselves call for "restoratives for lost manhood" (233). Even the most virile Rhett Butler-who, according to Jerilyn Fisher (2003) stands out as the only male who survives the Civil War "with his masculinity unquestioned" (119) - still fails to convince us (readers) of his full masculine potential as well as of his narrative authority. In choosing to go back to "the old ways" of Charleston and by relinquishing the qualities that had initially distinguished him from effeminate and submissive characters like Ashley-qualities such as independence, strength, and decisiveness-Rhett fails, in the words of David B. Sachsman (2007), to reinvigorate Southern masculinity, since "even Rhett, a blockade runner and gambler [. . .] subscribes to the final element of the Lost Cause myth by helping the night riders to clean out the encampment of homeless former slaves and avenge the attempted rape of Scarlett" (239).

16. In Ripley's Scarlett: The Sequel to Margaret Mitchell's Gone with the Wind, Ashley continues to be painted as "tall, thin, and colorless, [with] his pale gilt hair now almost gray, his pale stricken face as empty as his staring, unseeing gray eyes" (3).

17. Most importantly maybe, it is hard to resist the cameo that the packaging wears. Ashley is also shielded from considerations of ugliness because, the narrator reminds us, he is wearing "the head of a Medusa in cameo in his cravat pin." (34) The mythical reference to the Medusa may be interpreted here as a masculine fear of castration via the shield of Perseus, which was a mirror in which he could safely regard the face that otherwise turned men to stone. That it is Scarlett who notes this detail as Ashley is departing for the battlefield is significant, especially since the opening words of the novel are "Scarlett O'Hara was not beautiful." (3) According to the legend, the Medusa, a devotee to Athena and serving in her temple, was raped by Poseidon. For 
this reason, the angered Athena made this beautiful maiden into the strange figure with the snakes for hairlocks whose gaze turned men to stone. Via this reference, Ashley-turned into Perseus through reference to the Medusa-may be said to escape the fixity of the gender definitions that have been clearly stated by the Tarleton twins from the beginning of the novel. Ashley can be seen as attempting to shield himself from Scarlett-turned-into-Medusa's gaze.

\section{ABSTRACTS}

By examining the ways in which Margaret Mitchell's novel Gone With the Wind (and the character of Scarlett O'Hara specifically) contests heteronormative, patriarchal, masculine constructions of Southern (ideal) femininity, this essay argues that Scarlett's "ugliness" forces us to widen our perspective on Southern feminine beauty and purity and contributes to challenging the tropes of white Southern masculinity and femininity. The presentation of Scarlett is worthy of note because of the way it demonstrates the terrains of feminine difference and ugliness as complex (and enduring) fields for discussion.

En examinant les façons dont le roman de Margaret Mitchell Autant en emporte le vent (et le personnage de Scarlett O'Hara en particulier) conteste les constructions hétéronormatives, dominantes et patriarcales de la féminité (idéale) du Sud, cet article propose que la « laideur » de Scarlett (mentionnée et décrite en détail dès les premières lignes du texte) contribue à remettre en question les tropes de la masculinité et de la féminité blanches du Sud. La présentation de Scarlett nous intéresse car elle démontre que les terrains de la différence et de la laideur féminines sont des champs de discussion complexes (et durables).

\section{INDEX}

Keywords: Margaret Mitchell, Gone With the Wind, beauty, ugliness, male gaze, the South, history and myth, historical romance

Mots-clés: Margaret Mitchell, Autant en emporte le vent, beauté, laideur, regard masculin, Sud, histoire et mythe, romance historique

\section{AUTHOR}

\section{EMMELINE GROS}

BABEL, Université de Toulon 